\title{
The Apache Diaspora
}




\title{
AMERICA IN THE NINETEENTH CENTURY
}

\author{
Series editors \\ Brian DeLay \\ Steven Hahn \\ Amy Dru Stanley
}

\begin{abstract}
America in the Nineteenth Century proposes a rigorous rethinking of this most formative period in U.S. history. Books in the series will be wide-ranging and eclectic, with an interest in politics at all levels, culture and capitalism, race and slavery, law, gender, and the environment, and regional and transnational history. The series aims to expand the scope of nineteenth-century historiography by bringing classic questions into dialogue with innovative perspectives, approaches, and methodologies.
\end{abstract}




\section{The Apache Diaspora}

Four Centuries of Displacement and Survival

\section{Paul Conrad}

Published in Cooperation with the William P. Clements Center for Southwest Studies,

Southern Methodist University

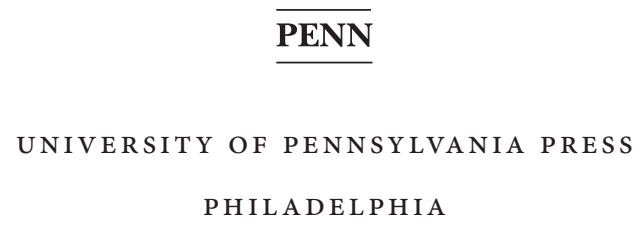

PH I L A D L P H I A 
Copyright $\odot 2021$ University of Pennsylvania Press

All rights reserved. Except for brief quotations used for purposes of review or scholarly citation, none of this book may be reproduced in any form by any means without written permission from the publisher.

\author{
Published by \\ University of Pennsylvania Press \\ Philadelphia, Pennsylvania 19104-4112 \\ www.upenn.edu/pennpress
}

Printed in the United States of America on acid-free paper

1355791086642

Library of Congress Cataloging-in-Publication Data

Names: Conrad, Paul, author.

Title: The Apache diaspora : four centuries of displacement and survival / Paul Conrad.

Other titles: America in the nineteenth century.

Description: 1st edition. | Philadelphia : University of Pennsylvania Press, 2021. |

Series: America in the nineteenth century | "Published in Cooperation with

the William P. Clements Center for Southwest Studies, Southern Methodist University" |

Includes bibliographical references and index.

Identifiers: LCCN 2020037029 | ISBN 9780812253016 (hardcover)

Subjects: LCSH: Apache Indians-History. | Apache Indians-Migrations. | Apache Indians-

Relocation. | Apache Indians-Government policy. | Apache Indians-Ethnic indentity.

Classification: LCC E99.A6 C595 2021 | DDC 979.004/9725—dc23

LC record available at https://lccn.loc.gov/2020037029 